\title{
The Instrumentalization of Metaphors in the Management Field: Reflections from the use of the Book "The Art of War" on Business
}

\author{
Luiz Gustavo Lara ${ }^{1, *}$ \\ ${ }^{1}$ Universidade Positivo, Curitiba, PR, Brasil \\ Fabio Vizeu ${ }^{1, \dagger}$ \\ ${ }^{1}$ Universidade Positivo, Curitiba, PR, Brasil \\ Elizeu Barroso Alves ${ }^{1, \Omega}$ \\ ${ }^{1}$ Universidade Positivo, Curitiba, PR, Brasil
}

\begin{abstract}
The debate about the use of metaphors in the organizational context in the last decades has not been exhausted, especially in discourse studies. Inserting itself in this discussion, the present essay problematizes the anachronistic dimension in the use of metaphors in the field of management. From a hermeneutic-critical perspective, we argue that the use of metaphors in managerial literature sometimes reflects a utilitarian and anachronistic distortion of the contexts originating in metaphorical symbolic forms. In this sense, the strategic use of language can inhibit the interpretive autonomy of individuals, that is, colonize their interpretive horizons by the persuasive induction of simplistic and utilitarian worldviews about organizational reality. We use the essay form as a method, and we rely theoretically on Alvesson's critical approach, on the hermeneutics by Gadamer and Ricoeur, and on Habermas' Critical Theory. We illustrate our argument by recurring use of the work "The Art of War" as a metaphor for managerial practice.
\end{abstract}

\section{KEYWORDS}

CORRESPONDING AUTHOR

Metaphor, Critical Hermeneutics, History, Management Language, Art of War

* Luiz Gustavo Lara

E-mail: luizusf@hotmail.com

${ }^{\dagger}$ Fabio Vizeu

E-mail: fabio.vizeu@gmail.com

$\Omega$ Elizeu Barroso Alves

E-mail: elizeu.a@uninter.com

\section{FINANCIAL SUPPORT}

We thank CAPES for their support via PROSUP-CAPES.

Received: $12 / 04 / 2018$

Revised: 26/09/2018.

Accepted: 15/10/2018.

Published Online: $11 / 07 / 2019$ 


\section{INTRODUCTION}

The use of metaphors is a much-debated issue, but one that has not been exhausted yet in the field of organizational studies (Cornelissen et al., 2008, Grant, Oswick 1996, Tsoukas, 1991). In this debate, we highlight the reflection on metaphor as a discursive strategy, explored by theorists who consider that knowledge about the reality of organizations are linguistic constructions full of metaphors (Astley, 1985). In addition to academic use, metaphorical discourse reveals itself as a linguistic resource capable of creating and signifying reality for the individual exposed to it. Metaphorical language sustains relations of power and creates zones of intersubjectivity, which support social relations. For this reason, the organizational world proves to be a fruitful field of study from the social perspective of language (Alvesson, 2013).

By recognizing the wide range of possibilities for approaching the use of metaphors in the field of Organizational Studies (OS), we fill a very particular point of observation to appraise critically the use of metaphors as a discursive resource in the corporate context: that of the critical hermeneutics. This perspective is based on the ontology of language and the discourse is taken as an essential element of human relations and of the historical process concerning the formation and maintenance of life in society (Ricoeur, 1990; Habermas, 1987a).

We start with the premise that, once the condition of reality is signified by language, it is impossible to express a neutral or impartial worldview (Astley, 1985, Astley \& Zammuto, 1992, Habermas, 1987a, 2001). This is a consequence of the condition which, in order to refer to reality, we express interpretive horizons anchored in historical contexts connected to the cultural tradition in which we are inserted (Gadamer, 2007). This consideration is fundamental to understanding the risk of alienation when an individual, in an unthinking way, consumes certain utilitarian interpretations of reality that are seductively offered by metaphorical discourses.

Just like the idea of discourse, we understand the anachronism matter from the linguistic turn of the human and social sciences fostered by philosophical hermeneutics (Gadamer, 2007, Wittgenstein, 1968). Human and social contexts are constituted by a cultural reference that is historically situated in time and space. However, these different historical contexts connect dialectically, constituting themselves by the diachronic approach and at the same time by the tension and search for separation. This is how our cultural references connect and are simultaneously a version of their historical past (Gadamer, 2007) and their denial (Koselleck, 2002). Anachronistic imports of forms of symbolic culture from distant times can break the linguistic tradition of a tradition and promote empty interpretations of their original contexts.

From a theoretical-analytical perspective of the social context of production and consumption of metaphors in the corporate world, this essay problematizes, particularly, the situations in which they are produced under appropriations of cultural symbols and distant historical times. Thus, we put effort to advance a little more in a critical reflection on the metaphor as a strategy of the organizational discourse that instrumentalizes subjectivities. In this sense, we support Mutch's (2006) idea that metaphors used in the organizational context must be constantly (re) examined, because if it does not occur, investigations about (and even the comprehension of) these realities may become less productive.

We intend to propose a hermeneutical theoretical reference for the critical analysis of the anachronistic use of metaphors as an organizational communicative distortion. Our contribution is to build an analytical place from where one can interpret, from where it is possible to reflect on such mechanisms and to glimpse possibilities of less committed discursive interactions. In 
BBR 16

this sense, when unveiling sophisticated mechanisms of communicative distortion based on the production of meanings by metaphorical anachronism, the latent possibility of encounters with the world is promoted through interpretive horizons not colonized by corporate interests.

For this purpose, we state that the use of metaphors as anachronistic simplifications can result in a deliberate process of inducing meanings that restrict the autonomous comprehension of reality in the corporate environment. This promotes a kind of peculiar alienation: that in which the individual is alienated from their own interpretative references. That is, by exploring the consequences of the anachronistic dimension in the use of metaphors, we contribute to understand how this communication strategy inhibits the interpretive autonomy of the individuals in the organizations, preventing them from their own experiences, besides cultural, cognitive and even ethical and moral references.

In the social field of Management, the anachronistic use of symbols and narratives from other historical contexts can be problematic. Sometimes they offer seductive interpretative packages that are decontextualized and simplify the organizational reality. They are offered as a shelf of metaphors used selectively according to certain interests not always stated to those who consumed such interpretations (Alvesson, 2013). The articulation of these anachronistic discourses in managerial literature, including the academy (Vizeu \& Matitz, 2018), induces individuals to do interpretations in an uncritical way as an objective reference of their own organizational reality. Such linguistic mechanisms prove to be sophisticated means of instrumentalizing the subjectivity of members of organizations (Pagès et al., 1987; Vizeu \& Cicmanec, 2013).

To exemplify and illustrate our statement, we analyze the current use of the war metaphor, particularly expressed by the diffusion of the work "The Art of War" in managerial literature and corporate media. We question the anachronistic instrumentalization of this metaphor by recreating the narrative from its original context to promote legitimacy to power asymmetries and managerial practices of the contemporary corporate world. We problematize the axiological divergences between its production context in ancient China and its taking as inspiration for managerial practices in the present market organizations.

We built our argumentation inspired by the Adorno's method (1986) essay form proposal, defended by Meneghetti (2011), as being the most exploitable possibility in the field of OS. The advantage of this essay method is its intent to awaken individuals to new possible interpretations of the same reality, a process of emancipation in the hermeneutical sense, through questions "that guide individuals to deepest reflections" (Meneghetti, 2011, p. 321).

\section{BASIS OF CRITICAL HERMENEUTICS: LANGUAGE, INTERPRETATION AND IDEOLOGY}

According to Philosophical Hermeneutics, the interpretation of the world is a construction built from a linguistic tradition in which the individual constitutes himself as a being (Gadamer, 2007). The starting point of this approach explicitly explains the ontological character of language and points out that what exists is language. It is, therefore, imperative to understand the reality, whose limits of intelligibility are the limits of language itself as a form of human interaction (Wittgenstein, 1968).

This ontological posture of hermeneutics has contributed to the linguistic turn of the human and social sciences, bringing immediate consequences for the construction of social thought. This is because it is understood that, since the process of socialization, cognition occurs essentially 
through the linguistic dimension of associations between the apprehensible signs world, their codification into signifiers and their storage in memory. This mechanism operates the articulation of meanings in an abstract world of thoughts and supports new interpretations of reality (Luria, 1986).

Considering the assumptions that (i) thought is language (Luria, 1986); (ii) the world is a linguistic representation articulated by the individual connected to the linguistic tradition in which he/she is acculturated (Gadamer, 2007); (iii) the meanings shared among a linguistic community form an intersubjective zone constituting the world of life where rational beings are able to communicate and organize themselves in society (Habermas, 1987a); and (iv) the linguistic constructs of that sociohistorical context support the contingent interpretation of the individuals in their encounters with the reality of a world in constant construction (Mutch, 2006). The semantics of language is dynamic, that is, it changes over time through infinite dialogical exchanges between individual encounters with the world (Ricoeur, 1990), the linguistic tradition is conveyed by history (Lawn, 2011), that is, by the linguistic repertoire shared by the members of a community (Astley \& Zamutto, 1992). It is in this sense that Gadamer understands language as being a social, cultural and historical phenomenon. Thus, "any detailed study should begin with an appreciation of this vital fact" (Lawn, 2011, p. 107).

Nevertheless, the language that signifies the world is not able to describe it neutrally (ASTLEY, 1985). This premise gives us the opportunity to take a critical stance on philosophical hermeneutics, constituted especially in the proposals by Ricoeur (1990) and Habermas (1987a, 1987b). In this sense, Habermas (1987a) points out that language and the interactions that derive from it can also maintain the structures of power and domination prevailing in modernity. Therefore, the world of life, in which nature is communicative, shows itself as being susceptible to a form of social domination operated by communication. Regarding this aspect, Habermas (1987a) highlights that the lifeworld suffers from deformities due to the strategic instrumentalization of communication for economic purposes and maintenance of power.

Within the Critical Hermeneutics perspective, besides Habermas, we also highlight the theoretical-analytical contributions by Ricoeur (1990). This author considers that the main task of this approach is to reveal the ideological bases - specifically its dimension of social domination - in the interpretation and interaction processes mediated by language, to open possible worldviews, which were intentionally suppressed. In other words, becoming aware of the ideology dimension contained in a language evinces that what is before our eyes reveals itself as a linguistically constructed reality, subject to be, therefore, a construction instrumentalized by the processes of domination.

In the particular case of the corporate organizational context addressed here, we also see the ideological language dimension, which Habermas (2001) and Ricoeur (1990) referred to. In many situations, Management appropriates meanings and discursive forms unrelated to its world and redefines them in a convenient way to induce interpretations with selective transpositions of meaning. In this sense, it generates the conditions to conduct strategically manipulated communication processes to the instrumentalization of the organizational subject. An interesting study, which reveals such discourse instrumentalization is the one accomplished by Vizeu and Cicmanec (2013) about people management practices and the use of motivational jingles as a discursive strategy. The authors explored the subtlety of the communicative distortion operated by the music, which contributes to reproduce the corporate ideological content and to persuade the laborer to engage in causes whose final purposes are not always communicated to them. 
It is from this hermeneutic-critical view that we intend to scrutinize the metaphor as a discursive strategy. It is taken simultaneously as a communicative resource for the intersubjective semantic construction, a language strategy that enables the intelligibility of certain lifeworld references; however, considering the structures of social domination, metaphor emerges as the manifestation of ideological contents, and is operated instrumentally to promote resignation to the condition of not being allowed to think outside the meaning fixed by ideology.

\section{A CRITICAL-HERMENEUTICAL VIEW ON THE USE OF METAPHORS IN THE MANAGEMENT AREA}

For Alvesson (2013), metaphors are essential in people's relationship with reality and, for this reason, they are important discursive resources and intersubjective interactions for the organizational context. In this respect, it is important to consider that the theoretical constructions over organizations have metaphorical constructs (Morgan, 1996; Mutch, 2006). It is remarkable the way some authors, such as Morgan (1996) and Mintzberg, Ahlstrand \& Lampel (2010), model images to refer to a dimension of organizational reality, promoting a rich comprehension of possibilities about this object, even if it remains in provisional character. Likewise, metaphors are also widely used in the communicative interaction of practitioners, those who live the reality of organizations: managers, employees, businesspersons, experts, etc., all use metaphors to articulate meaning and mediate their relationships and their grasp of organizational reality ${ }^{1}$

Even considering the wide use of metaphors in the context of organizations, a peculiarity must be taken into account. It must be considered that these constructions are loaded with meanings, which belong to the linguistic tradition and to a context which differ from what is meant to be. For example, Morgan (1996) presents the metaphor of contemporary organizations as psychic prisons, and explains this image from the famous allegory of cave prisoners, told by Plato in his piece "The Republic", written around the fourth century BC, and this is done by disregarding the great differences between the contemporary social and historical context and that of Ancient Greece. This way, much of the metaphorical expressions used in the organizational context are limited by the distance to the context which originated them, that is, metaphors form conceptual systems built from a socially and historically contextualized point of view (Matitz \& Vizeu, 2012); therefore, they are closely connected to the linguistic tradition of the social group of their origin (Lawn, 2011).

Prior to metaphors that keep meanings anchored in anachronisms, one must recover the reason that led to that choice for the production of meanings in a reality far from the one which originated the metaphorical artifact. It means, far from being a random selection, the metaphors in use carry an associative charge that deserves to be scrutinized in order to prevent interpretation from taking paths, which lead to an unproductive or little refined inquiry (Mutch, 2006). This way, it is possible to avoid confusion about the degree of sustained similarity, or that some characteristics are selectively used as an argument of authority to legitimize a preconceived worldview. Reducing metaphors to an instrument of meaning fixation is like imposing a certain point of view on an individual without them being allowed to question it.

1 Although it is possible to examine the uses of metaphors among different organizational theories, the object of this essay is the discourse addressed to the practitioner, expressed in the so-called managerialist literature. This brief statement was made only in an illustrative way. 
The interaction of the individual with what is real, that is, one's subjective experience of reality, interpret the world. It is as if the individuals were guided by others' pre-conceived interpretations, offered in a seductive way as some sort of meaning frame that discourages one from having their own encounter with the world. In this sense, metaphorical discourse thinks of the individual's expenses (Dunker, Paulon, \& Milán-Ramos, 2016), suppressing their ability to interpret their own reality from the references of their own life trajectory.

In this scenario, the managerial ideology, conscious or unconsciously from the speaker's view, creates conditions for the establishment of a systematic process of the organizational members' imaginary manipulation, in order to generate positive subjective experiences of a reality version about which they do not know the consequences of the actions in course (Vizeu \& Cicmanec, 2013; Forester, 1994). The concreteness of these experiences can be managed by the organization, since the language employed is not only a mechanism for developing reality, but also the condition for experiencing the world (Ricoeur, 1990).

In Management's literature - here understood as the formal discursive expressions in use by practitioners and manifested in different vehicles, such as specialized magazines for corporate audiences, websites, newspaper news, and internal corporate communications - there are numerous interpretive schemes to choose from as a useful semantic content on a shelf of metaphors (Alvesson, 2013). In these efforts of metaphorical discourse, the excessive simplifications of organizational complexity also seem to corroborate the formation of resigned, if not alienated, individuals who are satisfied with preconceived interpretations and do not encourage themselves to interpret the corporate world from their own significant references.

In some situations, the individual is tempted to consume a simple reality interpretation, reducing the possibility of growing a self-signification of their work (means, results and consequences) and training themselves to call on explanations which decrease the stress and discomfort before the contradictions lived in the organizational world, as suggested by Pagès et al. (1987). The authors point out that the effectiveness of mediation strategies in organizations (including strategies of symbolic and ideological manipulation) is taken by their ability to make individuals kinder. Individuals are encouraged to use a template of systematically elaborate interpretations to signify their work context without threatening the status quo. These meanings are pre-determined by the domination and control systems, which make the individual look at the world from a comfort zone, on a shallow level, without contradictions or need to think for themselves.

Metaphorical phrases, such as "to carry the company's flag", "to go into battle", or, as Vizeu (2010) states, the use of jargons which demonstrate solidarity in a non-experiential reality in the aggressive practice of Management - such as 'we are all a team' or 'we are in the same boat' - are invested to make members engage in managers' particular interests presented in a masked way (Vizeu \& Cicmanec, 2013).

In order to better exemplify how metaphors can be operationalized as discursive resources for restricting interpretation, the negative dimension of ideology (Ricoeur, 1990), we will now offer a brief appreciation of the war metaphor made explicit in the contemporary organizational context from the idea of "business in war ". In our analysis, we will have as a point of critical reflection on the anachronistic character of this metaphor, considering that it is commonly expressed in social references from past contexts. One of the most renowned is, precisely, the set of ideas of the text 'The Art of War', whose origin goes back to Ancient China. 


\section{SUN TZU AND 'THE ART OF WAR':}

\section{A HERMENEUTICAL-CRITICAL ANALYSIS}

Methodologically, in order to take our appreciation, we got inspired by Ricoeur (1990) and Habermas' (1987a, 1987b, 2001) perspectives. Thus, considering the mechanisms of the original symbolic forms production means to avoid anachronistic interpretations that legitimize some visions of the corporate world, constituting an analytical lens that allows us to be vigilant about the domination aspects through communication.

The Art of War is a text whose compilation is attributed to the war conception about the sociohistorical context of Ancient China. However, this paper was contemporarily imported by the management discourse as an instrument to legitimize a metaphorical narrative that "Business is War" and, therefore, the corporate context is a battlefield. Such literal references in Sun Tzu's texts are common analogies to the business world, for example, Muniz (2008) and Nunes (2011).

Considering such different historical context associations - which are about to be presented - it is reasonable to question the subjacent interests which support the choice of this work in an anachronist form to endorse the views that the organizational world, somewhat, resembles to Ancient China.

Having this exposed, we took the following steps: first, we searched the historical context of 'The Art of War' text production, beginning from the comprehension of the ordering power structures of the linguistic community belonging to that period and from analyzing the sociohistorical context of the senders and receivers of the original concepts to identify the significance conditions of this symbolic form; in a second moment, we observed the ideas "The Art of War" transmitted and its reading/reception in the current context. These studies about the different sociohistorical contexts gave us conditions to perform a critical analysis of the ideological sense unfolding in the metaphor reproduction of War in the corporate environment.

Analyzing a work whose author's biographical data are not accurate, not even being sure that such authorship is true, leads to an analysis that shall be treated as a symbolic authorship as well, taking into consideration the possibility of having a collective authorship, a kind of folkloric product. Thus, the central idea of military thought chains in Ancient China was to provide the means of giving power to the most capable party, for only this way it was possible to have peace and social order again (Bueno, 2011).

\subsection{Historical context of the 'The Art of War' production}

Ancient China is characterized by a certain convergence and cultural longevity. Even after the appearance of the first dynasties, forming distinct political units, there were no cultural disruptions that overshadowed or denied a common root (Marchionatti, 2012). China's history is, in essence, the story of people with a relatively unified cultural identity, which began with communities formation along the Yellow River and gave rise to a linguistic system that has remained structurally the same for about three millennia (Watson, 1968).

The condition of having a shared language in the empire contributed to the maintenance of that people's cultural identity (Ramos, 1999). Its culture, unseparated from spoken and written language, is marked by the artistic production refinement, which portrays its mythology (Bueno, 2011). Symbols and myths were created in that culture throughout its social and historical development, being the idea of war one of the most important features. 
The war was part of that civilization from the narrative of its origins, creating metaphors, which helped to interpret and understand the disputes between dynasties throughout the history of the ancient Chinese empire. Such metaphors inspired the development of combat techniques, which ensured the territorial expansion and marked the power struggles between the dynasties (Marchionatti, 2012). During the Neolithic period, current China was formed by villages along the Yellow River, and the dynastic period originated from this arrangement, marked by the dynasties rivalry, in which the Zhou dynasty ruled for a longer time - from 1046 B.C. to 256 B.C. (Marchionatti, 2012). However, over the centuries, this dynasty weakened and the empire territory became the scenario of disputes marked by a violent period of civil war (Bueno, 2011). As one historian suggests, the sense attributed to War in this period is very peculiar:

Most history books of this period - such as the Stories Treaty and the Spring and Autumn Annals - had already talked about battles, warrior heroes, but at no point did they praise war as a wonderful event, but as a necessity or as a result of some great crisis. In another book, the Treaty of Poesies, war is mourned in several poems, and regarded as a social calamity (Bueno, 2011, p. 17).

From the sixth century B.C., the historical data suggest that the Zhou no longer had kingdoms unifying power; therefore, China had no emperor. In this cultural context, the political thought of Ancient China was directed to the idea of War as a crisis; the doctrines, which emerged emphasized statements that intended to systematize a method for solution. That is, for the intellectuals from that period there was a need to study possibilities of action for conflict situations - when peaceful solutions were no longer possible (Bueno, 2011). Thus, it was only when the war was inevitable that this resource would be used, fact which would justify its studying, for in this situation, the winner would establish the rules for the kingdom's future. Therefore, in the production context of the text The Art of War, war was an instrument for the State stability, an exceptional necessity, a matter of life and death literally (Bueno, 2016).

Well known in the West as 'The Art of War', Sunzi Bingfa - which is best translated as the law of War - is supposed to have been written by an enigmatic Chinese figure: Sunwu, also known as Sunzi or Sun Tzu. The first record of his citation was set in 100 B.C. by Su-ma Chien, who described Sun Tzu as a general of the King of Wu; therefore, it is estimated Sun Tzu had lived during the fifth century B.C. (Clavell, 1985). The period in which Sun Tzu might have lived - the period of the Zhou dynasty - was marked by the empire fragmentation, which might have contributed to the urge of organized armies instead of hordes of warriors (Bueno, 2011). However, there is the possibility that he did not even exist, being a folk character attributed to Ancient China. On this point, Bueno (2011) states that Sun Tzu, as a general in particular, was probably a Western creation, whose positive story was told from some characters' individual and heroic actions, to meet a cultural need of European readers.

In the 11th century A.D., the historian Yi Zhengzi tried to seek greater evidences about Sunzis life, but it was in vain. $Y i$ even declared he never existed and was supported by other authors. Until recently, Sunzis existence as a historical figure has been contested. (Bueno, 2011, p. 49)

Despite the doubt about existence or not of Sun Tzu, it must be recognized that "The law of War" represents the identity of Chinese military thought (Bueno, 2011). Understanding the Art of War, then, consists in understanding the basis of that culture's military thought. The personification of the work in the figure of Sun Tzu can be a translation mechanism of a traditional 
knowledge for the military leader heroic conception, common to the western culture, which translates them, and was instrumentally appropriated by Management.

\subsection{The translation/Reception of "The Art of War" in Modernity AND ITS IDEOLOGICAL USE IN THE CORPORATE WORLD}

In the West, 'The Law of War' became 'The Art of War', and in order to value this teaching as being the thought fruit of the supposed general who had an extraordinary vision of military activity. Thus, Sun Tzu turned out to be a great inspiration of leader and strategist, a model of general who would have inspired modern military characters.

The first translation of The Law of War into a Western language happened in 1782, the 75 chapters, which originally circulated in China, were compiled in 13. The translation was fruit of the Jesuit priest Joseph Marie Amit's work, who had been sent to missions in that country. Being French, Joseph translated the work to his native language, fact that allowed Napoleon to access that document while he aimed to conquer territories in Europe (Clavell, 1985).

It was only in the 20th century, more precisely in 1905, that the thirteen-chapter collection was translated into English by Everard Ferguson Calthrop, a British artillery officer killed on the battlefield during World War I. This way, it must be considered that his engagement in the British Army was a bias during the translation process to that language. Throughout several translations, there has been a gradual process of work westernization, a kind of romanticization with frequent language adaptations to Western values and contemporary culture (Bueno, 2011).

Until the first half of the 20th century, the western consumption of that text was restricted to the military strategy context. However, with the rise of strategic management and the search for inspiration in militarism (Vizeu \& Gonçalves, 2010), the paper happened to be accepted and valued by corporate leaders. Considering the conditions of the work reception in the Management world, the incorporation of the War metaphor in business takes place by the interposition of the idea related to 'competitiveness' and 'war', as well as by the exchange between the company's manager figure into the general of the army. Being related to the first aspect, there are innumerable direct associations between the competitive environment and the war. McNeilly (1998) approaches them quite objectively, including the use of geographic inferences to legitimize his view: "In the flourishing world of Asian business, Sun Tzu's strategic principles are revered and have been applied by countless leading executives to run their companies towards prosperity."

However, when this metaphoric association is taken into consideration from the social and historical references of the original context, we see this association as a dangerous simplification. In this respect, Bueno (2011, p. 210) states that "we have to keep in mind that in China the idea of associating war with commercial competition, as it is widely spread in the West, is somewhat intimidating and too aggressive." The analysis of the social and historical context of Ancient China suggests that, in the original context of this work, the War is considered a situation of exception revealed by a social crisis. It is taken as a last resort, even if the domain of its function is essential for the imperial order maintenance.

In fact, the analogy between business competition and military war produces a metaphorical component that becomes more profitable for corporate interests. This is the analogy between the company manager and the army general. This translation is explained by the concept of strategy itself, which carries in its etymology the definition of 'the general's activity' and, in the modern context, is translated as the activity of the company's main manager (Vizeu \& Gonçalves, 2010). Yet, in the western culture, the military leader figure is commonly seen as the hero, an aspect 
observed in modern administrative thinking because of the importance given to the administrator himself, understood as the central subject for the economic enterprise success (Vizeu, 2010). This is clear in such texts as Wess (1987), which deals with the teachings of Hun General Attila's leadership for management practitioners in the business world, or in the narrative of the following excerpt from an article in business review, which parallels the book of Ancient China with the contemporary concepts of business strategy:

$[\ldots]$ in the process of training a manager, which books are indispensable? What titles cannot be left out, especially during graduation? The InfoMoney team, with the help of coaches and teachers focused on business world, has compiled a list of 7 important works for these professionals. [...] 4. The Art of War (Sun Tzu). [...] The book deals with strategies based on SWOT Analysis (Strengths, Weaknesses, Opportunities and Threats) (Nunes, 2011).

However, this metaphorical association between a general and a strategist manager, even being possible, may decrease the understanding of some elements that distinguish the activities of militarism and modern corporate management. This association intends to naturalize the managerial competence as a heroic dimension, found in narratives of military battles winners. These narratives romanticize the history of generals or troop commanders as if they were purely rational individuals assuming that managers can hold absolute control of the competitiveness process, something that has been questioned as a dangerous fallacy of the modern administrative thinking (Clegg, Carter \& Kornberger, 2004).

Another negative consequence of the war metaphor for understanding the corporate sphere is to embrace military texts as a literal manual of managerial posture in non-military organizations. Some authors establish such understanding, for example, McNeilly (1998, p. 15): “[...] for many who would like to penetrate the strategic philosophy of Sun Tzu, there is no other resource but to read The Art of War and try to directly apply its quotes about military operations to current business problems." Other examples are the following extracts taken from articles published in business magazines:

Mario Grieco, Bristol-Myers Squibb general manager in Brazil and professor at the Business School of São Paulo, is one of them. This businessman has adopted 'The Art of War' as a bedside book since he has lived in the United States. 'War strategies are applicable to competition in the business world, they are interesting and effective' (Muniz, 2008).

The Art of War (Sun-Tzu), written by the Chinese General Sun Wu in the third century B.C. The book is popular among generals; Napoleon Bonaparte and Colin Powell read it. But Sun-Tzu and the Art of Business by Mark McNeilly understands that Charles Schwab's low-cost brokerage used a strategic principle of the Chinese general by offering shares at very low rates to the mass: the advantage of change in circumstances (Isto é dinheiro, 2003).

It is clear in these examples that the differences between the context of war in antiquity and the practice of management in corporations are completely disregarded. How can one literally follow Sun Tzu's thirteen books prescriptions in the world of organizations? As suggested by our analysis of the social and historical context of Ancient China, war at that time was associated with a crisis; does the contemporary corporate world also regard the activity of supposed corporate war as a crisis, a particular situation that requires extreme situations? We notice that such idea, if true, indicates a behavior that is useful to corporate interests.

Under the tutelage of Management's ideology (Vizeu, 2010), managers are conditioned to maximize the gain of capitalist organizations using all tools available to them. In this context, the 
metaphor of war becomes useful to induce a particular behavior: managers being induced to act as generals in command; and employees, as loyal soldiers in an extreme war context. Competition in the business world becomes naturalized as the extreme situation of war, a constant crisis that never ceases. In the same way, employees are developed to face their opponent as a rival in a fatal battle, ready to defend their organization with their own life. In fact, such metaphor about the organizational behavior becomes an interesting discursive strategy at the service of corporate interest by individuals who are more prepared to face the troubled competitive context of business. According to one author, on the employee profile caught in the strategic trap of the contemporary corporate world:

... the company needs subtle individuals capable of taking initiatives and of reacting as quick as possible, proving to own lightness and flexibility before unpredictable, constant and numerous events which they are confronted with. Everyone becomes a player, trying to win and having to succeed, even in the worst of conditions (Enriquez, 1997, p. 21).

It is to meet such challenges that the metaphor of war, as expressed in the translation of this essay, becomes ideologically interesting. It conditions expectations by creating a perception of context from extreme references, and verges the individual who works in the organization to perform a voracious (in relation to the enemies on the battlefield) and simultaneously disciplined (in relation to the interests of adjustment and non-confrontation with the rules of working conditions imposed by the organization) action.

When, for instance, McNeilly (1998, p. xv) states that entrepreneurs have valued Sun Tzu's teachings for they understand that "business, like war, is a dynamic and accelerated clash of wills, based on morality and machines," he reveals the discourse that naturalizes a social state of exception peculiar to war times - in which people kill, destroy, corrupt, sack, etc. - considering this form of coexistence combat an ordinary order of the commercial experience in the business markets. In this sense, it is difficult to understand McNeilly's position when, despite the direct associations between war and business, he sustains that both must be conducted ethically. This is to disregard the axiological abyss of the nature of agreements, which separate them, therefore, which differentiate the decision-making positions of their respective leaderships.

The main consequence of this metaphorical allusion to the corporate environment is to create the false impression that in order to achieve the corporation goals, anything goes in the business world. This association encourages the creation of a reality simulacrum, and is operationalized in the construction of a corrupted behavior pattern, which lacks good ethical references. It must be considered that we live in an ethical crisis in business, where character corruption is trivialized in the unbridled search for the economic result of companies (Sennett, 1999).

Underlying the objectivation of the corporate environment as a battlefield, there is the veiled induction to naturalize the asymmetric power relations that instrumentalize the individuals as human resources tamed to receive orders. This way, they act in the defense of interests without being fully aware of whom gets benefits with it or the consequences of their actions. It is a strategic use of communication, through manipulation of language, where understandings that discourage the individual are constructed to reflect critically on their own social context. The ideological domination aspect is manifested, therefore, with the attempt to limit interpretation (Ricoeur, 1990, p. 71).

The anachronism present in the use of The Art of War in business context does not seem to be mere sociohistorical context carelessness or disregard in which these ideas were originally thought. 
The diffusion of "The Art of War" in contemporary times is due to its discursive, ideological-based use, with the purpose of crystallizing ideas under the legitimacy of wise general assumed teachings.

\section{FINAL REFLECTIONS}

Metaphors are important linguistic resources because they support the individual in his hermeneutic encounters with the world - situations in which, in contact with the unknown, the individual builds the object unknown to them so far and which, through the linguistic interaction and processes of interpretation, before them, is reconstructed (Gadamer, 2007). However, when one is submitted to metaphors elaborated from symbolic forms constituted in a context, which differs a lot from the one that serves as reference for the interpretation of the world, there is the risk of being apart from the phenomena and the experience may not be sufficiently significant.

In Brazil, between 2010 and 2016, The Art of War was one of the ten best-sellers in the business category, according to the ranking of the PublishNews page - which gathers information from thirteen of the largest bookstores in that country. In addition to the work being commercially associated with the business area, there are numerous other publications that derive from it and associate Chinese philosophy with the Western business world, such as Gagliardi (2004), Krause (2007) and Sheetz-Runkle (2014). From principles to practical guidance, such works support the transposition of principles from the legitimacy of Sun Tzu's western narrative. In business media, these associations are also present. In the New York Times, one of the most important media magazines in the United States and in the world, a direct search using the terms Sun $T z u$ reveals 416 articles, which interpret some dimension of the contemporary world from text excerpts attributed to him.

Despite the remarkable presence of the book as a reference for Management practitioners discourse, we have seen in our essay that the metaphor of war - as presented in this type of text - shows important contradictions to explain the competitive environment and the corporate leadership, especially considering the way the translation of the war field occurs through the commerce/business field. On this point, Bueno (2011) recalls Maozedong, an expert in the reading of Sunzi, at any moment in his philosophical, moral, historical, sociological and educational writings made an analogy of military strategies belonging to the Law of War to other fields of life.

As a consequence, we see that the war metaphor use is reflected anachronistically as an expression of meanings and comprehension articulated by ideological interests, especially those which intend to mediate the relationship between the organization and its employees and managers (Vizeu, 2010; Pagès et al., 1987). Considering the perspective of discourse, we understand this process clarifies how suggestible individuals are caught in an interpretive trap, in other words, a systematic colonization of the imaginary (Schirato, 2004). This form of communicative action is capable of carrying elements that transcend the objectivity of stated goals.

For this reason, we suggest that the production of metaphors used as systematically distorted symbolic forms, used without regard to the peculiarities of their original contexts, serve as a mechanism of interpretation management that sediments asymmetries of power and, consequently, creates more subtle mechanisms of control and domination in the corporate context.

We consider that if organizational metaphors are appreciated from the criticism perspective, especially recognizing the ideological dimension contained in the language that de-characterizes it as a neutral system of meaning (Ricoeur, 1990; Habermas, 1987a), we enhance the understanding 
of its practical consequences, among the ones we focus here, specifically on the blocking of possible interpretations as a function of the utilitarian meaning fixation imposed by the corporate discourse.

Therefore, the contribution of this essay lies in revealing how the scrutiny of contextual aspects of different discursive forms construction can help us to understand such mechanisms of domination and control in the organizational context. In the particular case of using the war metaphor, we believe that clarifying its contradictions helps managers and employees to adopt a less naive stance on the meanings associated with different corporate discourses. In a very practical way, making business media consumers more aware of certain ideas implications and discourses enables them to have a more coherent attitude, empowering their conscious participation of the corporate world problems and contradictions.

The social and historical context rescue of the war metaphor - taken from the production context analysis of the book The Art of War - is useful to reveal how this anachronistic use of an idea can be strategically instrumented for ideological control interests (Pagès et al. al., 1987). In this sense, as Mutch (2006) suggests, the metaphors that anchor some approaches in the literature of organizations must be constantly reexamined to open up the possibilities of meaning instead of taking steps, which lead to the understanding loss of the organizational reality. This way, the potential of authentic encounters with the world is amplified, interpreting it in an unmanaged way, uncompromising with the managerial ideology.

\section{REFERENCES}

Adorno, T. W. (1986). O ensaio como forma. In G. Cohn (Org.), Sociologia: Adorno (pp. 167187). São Paulo: Editora Ática.

Alvesson, M. (2013). Understanding Organizational Culture. London: SAGE.

Astley, G. \& Zammuto, R. (1992). Organization Science, Managers, and Language Games. Organization Science, 3(4), 443-460.

Astley, G. (1985). Administrative Science as Socially Constructed Truth. Administrative Science Quarterly, 30(4), 497-513.

Bueno, A. A Arte da Guerra Chinesa: Uma história da Estratégia na China, de Sunzi a Maozedong. Rio de Janeiro: Creative Commons, 2011.

Bueno, A. (2016). Textos de História da China Antiga. Rio de Janeiro: Ebook.

Clausewitz, C. (1996). Da Guerra. São Paulo: Martins Fontes.

Clavell, J. (1985). A Arte da Guerra. Rio de Janeiro: Record.

Clegg, S. R., Carter, C., \& Kornberger, M. (2004). A “máquina estratégica”: fundamentos epistemológicos e desenvolvimentos em curso. RAE-revista de administração de empresas, 44(4), 21-31.

Cornelissen, J. P. et al. (2008). Metaphor in organizational research: context, modalities and implications for research - Introduction. Organization Studies, 29(1), 7-22.

Dunker, C. I. L., Paulon, C., \& Milán-Ramos, G. (2016). Análise psicanalítica de discurso: perspectivas lacanianas. São Paulo: Estação Letras e Cores (2nd ed.). São Paulo: Estação das Letras e Cores.

Enriquez, E. (1997). O indivíduo preso na armadilha da estrutura estratégica. RAE-revista de administração de empresas, 37(1), 18-29.

Forester, J. (1994). Teoria crítica e análise organizacional. Plural, 1, 131-148. 
Gadamer, H. G. (2007). Verdade e método I: traços fundamentais de uma hermenêutica filosófica. (8th ed.) Petrópolis: Vozes.

Gagliardi, G. (2004). Sun Tzu's The Art of War Plus, The Art of Management: Strategy for Leadership. Clearbridge Publishing.

Grant, D. \& Oswick, C. (1996). Metaphor and organizations. London: Sage.

Habermas, J. (1987a). Dialética e Hermenêutica: para a crítica da hermenêutica de Gadamer. Trad: Álvaro L.M. Valls. Porto Alegre: L\&PM.

Habermas, J. (1985b). Teoría de la acción comunicativa. tomo I: racionalidad de la acción y racionalización social. Madrid: Taurus.

Habermas, J. (2001). Conhecimento e interesse. In J, Habermas, Ciência e técnica como ideologia (pp. 45-92). Lisboa: Ediçôes 70.

Isto é Dinheiro. Alexandre, o Grande, para empresários. Retrieved from: https://www.istoedinheiro. com.br/noticias/negocios/20031015/alexandre-grande-para-empresarios/21147

Koselleck, R. (2002). The practice of conceptual history. Stanford: Stanford University Press.

Krause, D. G (2007). The Art of War for Executives: Ancient Knowledge for Today's Business Professional. New York: Tarcher Perigee.

Lawn, C. (2011). Compreender Gadamer. (3th. ed). Petrópolis: Vozes.

Luria, A. R. (1986). Pensamento e linguagem: as últimas conferências de Luria. Porto Alegre: Artes Médicas.

Marchionatti, W. (2012). China: velho e novo império. Porto Alegre: Edpucrs.

Matitz, Q. R. S. \& Vizeu, F. (2012). Construção e uso de conceitos em estudos organizacionais: por uma perspectiva social e histórica. Revista de Administração Pública, 46(2), 577-598.

Mcneilly, M. (1998). Sun Tzu e a arte dos negocios: seis principios estratégicos para executivos. Rio de Janeiro: Campus.

Meneghetti, F. K. (2011). O que é um ensaio-teórico? Rev. Administração Contemporânea, 15(2), 320-332.

Michaelson, G. \& Michaelson, S. (2010). A Sun Tzu. The Art of War for Managers: 50 Strategic Rules Updated for Today's Business. (2nd ed). Avon, MA: Adams Media.

Morgan, G. (1996). Imagens da Organização. São Paulo: Atlas.

Muniz, R. (2008). No mundo dos negócios, use a arte da guerra. Retrieved from: https://exame. abril.com.br/negocios/no-mundo-dos-negocios-use-a-arte-da-guerra-m0040214/.

Mutch, A. (2006). Organization theory and military metaphor: Time for a reappraisal? Organization, 13(6), 751-769.

Nunes, V. K. Veja quais são os 7 livros essenciais para os administradores. Retrieved from: https:// www.infomoney.com.br/carreira/noticia/2288584/veja-quais-sao-livros-essenciais-paraadministradores.

Pagès, M. et al. (1987). O Poder das organizaçôes. São Paulo: Atlas.

Ramos, N. R. A. (1999). Os reinos soterrados da China. Rio de Janeiro: Abril Coleçôes.

Ricoeur, P. (1990). Interpretação e Ideologias. Rio de Janeiro: Francisco Alves.

Savelle, M. Org. (1968). História da civilização mundial. Belo Horizonte: Ed. Itatiaia.

Schirato, M. A. R. (2004). O feitiço das organizaçôes: sistemas imaginários. (2th ed.) São Paulo: Atlas. 
Scott, A.O \& Dargis, M. (2018). Dear Movie Industry, We Have Thoughts. Retrieved from: https:// www.nytimes.com/2018/05/02/movies/dear-movie-industry-metoo-netflix.html.

Sennett, R. (1999). A Corrosão do caráter: conseqüências pessoais do trabalho no novo capitalismo. Rio de Janeiro: Record.

Sheetz-Runkle, B. (2014). The Art of War for Small Business: Defeat the Competition and Dominate the Market with the Masterful Strategies of Sun Tzu. New York: American Management Association.

Tsoukas, H. (1991). The missing link - a transformational view of metaphors in organizational science. Academy of Management Review, 16(3), 566-585.

Vizeu, F. (2010) Poder, conflito e distorção comunicativa nas organizaçôes contemporâneas. In Marlene Marchiori. (Org.). Comunicação e Organização: reflexôes, processos e práticas (pp. 251-268). São Caetano do Sul, SP: Difusão Editora.

Vizeu, F. \& Cicmanec, E. R. (2013). A música que encanta, o discurso que aprisiona: a distorção comunicativa em uma loja de departamentos. Cadernos EBAPE.BR, 11(1), 149-164.

Vizeu, F. \& Gonçalves, S. (2010). Pensamento estratégico: origens, princípios e perspectivas. São Paulo: Atlas.

Vizeu, F. \& Matitz, Q. R. S. (2018). Anacronismo Conceitual e Construção Social do Conhecimento em Ciências Sociais e em Estudos Organizacionais: uma Análise Crítica a partir da História Conceitual de Reinhart Koselleck. Revista Organizaçôes \& Sociedade, 25(86), 413-433.

Watson, W. (1968). A China antiga. Londres: GRIS.

Wess, R. (1987). Leadership secrets of Attila the Hun. NY: Warner Books.

Wittgenstein, L. (1968). Tratactus Logico-Philosophicus. Univ. São Paulo. 